
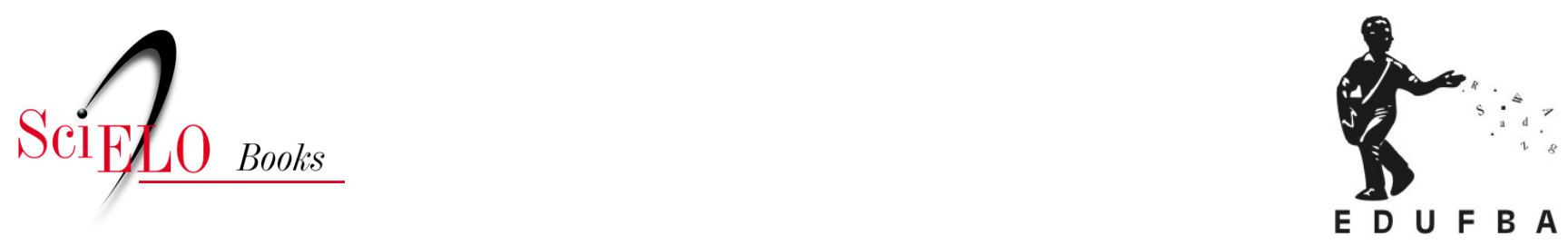

\title{
Prefácio
}

\section{Renato Ferracini}

FERRACINI, R. Prefácio. In: BRITO, M.S. O teatro que corre nas vias [online]. Salvador: EDUFBA, 2017, pp. 7-10. ISBN: 978-85-232-2001-3. https://doi.org/10.7476/9788523220013.0001.

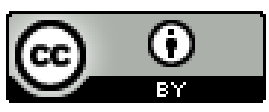

All the contents of this work, except where otherwise noted, is licensed under a Creative Commons Attribution 4.0 International license.

Todo o conteúdo deste trabalho, exceto quando houver ressalva, é publicado sob a licença Creative Commons Atribição 4.0. 


\section{Prefácio}

O mundo seria um lugar muito inóspito sem arte. Não só inóspito como ignorante, embrutecido, estúpido, odioso. Aliás uma boa parte da população brasileira está assim: ignorante, embrutecida, estúpida, odiosa, não somente por ignorância política e histórica, mas por falta de uma cultura de afetividade que somente a arte e a cultura podem trazer. A arte não é só necessária para artistas, mas para a vida. E não falo aqui de uma arte/cultura enlatada, massificada em pastiche e lançada às massas zumbis entre ighs e 22hs. Falo de uma arte que intensifica uma produtividade crítica e principalmente uma ação de inventividade de outras formas possíveis de modos de existência. A atual crise brasileira e mundial é, antes de mais nada, uma crise de inventividade. Tanto o centro, como a direita, como a esquerda (além daqueles que se dizem neutros, como se isso fosse possível!) se posicionam a partir de fórmulas centenárias já dadas. Não há propostas novas, não há coragem de nenhuma das partes em inventar outros modos de ação, de relação, de afetos. Falta inventividade, pois falta "treino" de inventividade. E esse treino somente a arte pode dar. Somente a arte desloca outros modos de ver as cores, o corpo, o som, as formas. Ela treina e promove afetividade e inventividade. Precisamos de uma política inventiva, de uma economia inventiva, de relações de poder mais abertas e inventivas. Como fazer isso sem viver isso ou "treinar" isso sem arte, sem cultura? A arte promove uma micropolítica afetiva para quem dela frui. Acredito muito que essa micropolítica pode se transformar em macro no tempo caso o "treino" de inventividade da arte fosse colocado em primeiro plano na esfera política e social. Mas não sejamos ingênuos, isso não vai acontecer... resta a luta micropolítica dos artistas. Resta-nos fazer micropolíticas e assim gerar essas Zonas 
Autônomas Temporárias (as TAZ de Hakim Bay) e atuar, como sempre foi, nos bastidores, nos undergrounds, para promover, pela e com a arte, uma resistência que seja uma Re-Existência.

Nesse sentido, ser artista é uma postura, antes de mais nada, ética. Desculpem-me os pedagogos da destruição mas definitivamente não se faz arte com violência, mesmo que o ato artístico seja violento enquanto radicalidade de proposta de deslocamento afetivo, político, crítico. A grande questão para os jovens artistas é: como promover essa violência estética, corpórea e radical tendo como postura de fundo uma ética da afetividade? O mundo já está por demais destrutivo para que busquemos uma estética pela destruição seja do que for. Sejamos radicais, rigorosos e verticais. Como promover outras coletividades, outros modos de produção tendo como base éticas afetivas? Uma ética, em última instância, do AMOR. Na Grécia usava-se muitas palavras para o amor, uma delas era o amor do tipo PHILIA. A essa forma de amor os gregos entendiam pelo que designamos hoje por amizade. Mas não essa de likes de facebook ou selfies em festas, mas uma mais vertical e potente. Aquela dos laços que são criados em batalhas pelos soldados. Philia era lealdade aos amigos, fidelidade ao crescimento e conhecimento do outro. A philia gera redes afetivas potentes e leais e, por isso, constrói um comum entre corpos, comum esse que valeria a pena o sacrificar-se por ele. A questão importante aqui é que o conceito de Philia aproxima o amor da política. De um fazer politico, ético e estético baseado em PHILIA, que busca construir um comum e não procurar ou ajustar um comum no conjunto de corpos. Não um: “vamos achar o que há de comum em nós?” Mas um salto para: "somos diferentes: vamos construir, criar, inventar um comum para nós?". As implicações políticas e sociais da invenção do comum são infinitas e potentes. No livro de Hardt e Negri, Commonwealth, verificamos que constituir um novo homem e uma nova sociedade implica radicalizar o amor, enquanto Philia - no comum de formas de vida, bens, afetos, imagens e conhecimentos. "O amor é uma força econômica." dizem eles. A Philia, e sua rede construída, tem uma força desmedida, vence a morte e opera resistência. Pode ser o princípio da organização (política) da produção. Acredito que caiba aos jovens artistas colocar isso em prática. Descobrir como colocar isso em prática...

É sobre essas questões de fundo que se assenta essa obra de Marcelo Sousa Brito. A obra além de ser uma análise crítica e conceitual sobre a relação teatro 
e cidade, teatro e urbanidade, possui a virtude de tratar o fazer teatral no espaço urbano como um grito ético e político. Faz dessa experiência um possível sopro de Philia que a performance urbana pode inserir no imaginário poético dos corpos (daqueles que passam e daqueles que fazem!). Possui o mérito de dar voz a muitos e grandes artistas e pensadores brasileiros sobre o tema, revelando o quão vertical e intensa é a produção dessa arte no país, além de colocar em diálogo potente as reflexões desses artistas brasileiros e contemporâneos com uma família de pensamento reconhecida no século XX e XXI como Rancière, Bachelard, Pavis, Merleau-Ponty, Féral, entre outros. A pesquisa de Marcelo foi vertical, tanto em sua reflexão conceitual como crítica, além do excelente mapeamento realizado a partir de entrevistas com grandes artistas e pensadores dessa relação arte e cidade.

Porém, a meu ver, o maior mérito da obra é discutir esse fazer poético urbano como uma forma potente de experiência poética. Ao focar o trabalho do ator nesse fazer, na última parte da obra, Marcelo nos obriga a pensar o trabalho do atuador de forma verticalizada. Ponderemos: quase toda experiência é imprecisa ou incontrolável. E feliz ou infelizmente o trabalho do ator está baseado nessa imponderabilidade. Presença, teatralidade e energia são conceitos difíceis não somente porque eles são heterogêneos, múltiplos e polissêmicos, mas principalmente porque eles são conceitos relacionais. São imprecisos, invisíveis, pois não são matéria palpável, mas forças que produzem relação. E mesmo na física - disciplina dura - a força somente pode ser definida pelos efeitos que causam nos corpos. Por isso hoje em dia falamos de efeito de presença, efeito de energia ou efeito teatral, pois são forças que somente podem ser definidas nos efeitos relacionais que elas causam. E poderíamos afirmar que a grande maioria dos efeitos que verificamos numa relação pode ser considerada imprecisa e incontrolável. Nossa função como ator é potencializar e proporcionar relação entre todos os elementos da cena (espaço, tempo, figurino, cenário, outros atores, público), criar um curto circuito relacional que eu chamo de "zona de turbulência": uma zona, um terreno que você ao mesmo tempo gera e é afetado por essa mesma zona criada por você. Se você consegue fazer isso você pode ser considerado ATOR. Portanto, a ação do ator é aquela que o insere numa zona paradoxal de ser receptivo e ativo ao mesmo tempo. Um campo de sutilezas e de efemeridade que só pode ser alcançado por um ato 
"receptivativo" que "habitua" o ator a relacionar essas sutilezas e forças numa composição no/do presente. E para tanto não existe um aprendizado concreto e objetivo. A única maneira de se aprender isso é experimentando.

O conceito proposto por Marcelo de intervenção viária possui o mérito e a força de aglutinar todas essas questões apresentadas: luta por um mundo menos inóspito, mais relacional, flerta com uma philia política a partir da experiência poética urbana. E ainda vivifica um ator que se coloca em seu paradoxo de existência: ao mesmo tempo controlável-incontrolável; ao mesmo tempo receptivo-ativo, assim como a própria vida.

Boa leitura! E como é uma obra que merece ser deglutida a cada palavra: bom apetite a todos!

Renato Ferracini (Lume - UNICAMP) 